\title{
Surfaces
}

\section{ADAPTING WEB ELECTRONIC LIBRARIES TO ENGLISH STUDIES}

\section{Christopher Douglas, Dennis G. Jerz et Ian Lancashire}

Volume 8, 1999

HUMANITÉS ET INFORMATIQUE : QUI A LES COMMANDES ?

HUMANITIES AND COMPUTING: WHO'S DRIVING?

URI : https://id.erudit.org/iderudit/1065075ar

DOI : https://doi.org/10.7202/1065075ar

Aller au sommaire du numéro

Éditeur(s)

Les Presses de l’Université de Montréal

ISSN

1188-2492 (imprimé)

1200-5320 (numérique)

Découvrir la revue

Citer cet article

Douglas, C., Jerz, D. G. \& Lancashire, I. (1999). ADAPTING WEB ELECTRONIC

LIBRARIES TO ENGLISH STUDIES. Surfaces, 8. https://doi.org/10.7202/1065075ar
Résumé de l'article

Le département d'anglais de l'Université de Toronto a mis au point UTEL, un site web d'enseignement et de recherche conçu pour mettre en lumière les différentes approches théoriques et méthodologiques de la littérature dans ce départment. Nous défendons la constitution par les universitaires de bibliothèques électroniques départementales afin de rendre disponible des essais, des notes, du matériel de lecture, ainsi que des bases de données. Une infrastructure institutionnelle, avec un système d'évaluation par les pairs et des objectifs cohérents, s'impose pour un tel projet. Il s'agit d'un type de modèle qu'il faut développer puisqu'on ne le retrouve sur le Web ni dans les sites individuels ou commerciaux, ni dans les sites de départements universitaires colligeant le plus souvent des renseignements administratifs.
Copyright @ C Christopher Douglas, Dennis G. Jerz et Ian Lancashire, 1999

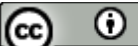

Ce document est protégé par la loi sur le droit d'auteur. L'utilisation des services d'Érudit (y compris la reproduction) est assujettie à sa politique d'utilisation que vous pouvez consulter en ligne.

https://apropos.erudit.org/fr/usagers/politique-dutilisation/ 


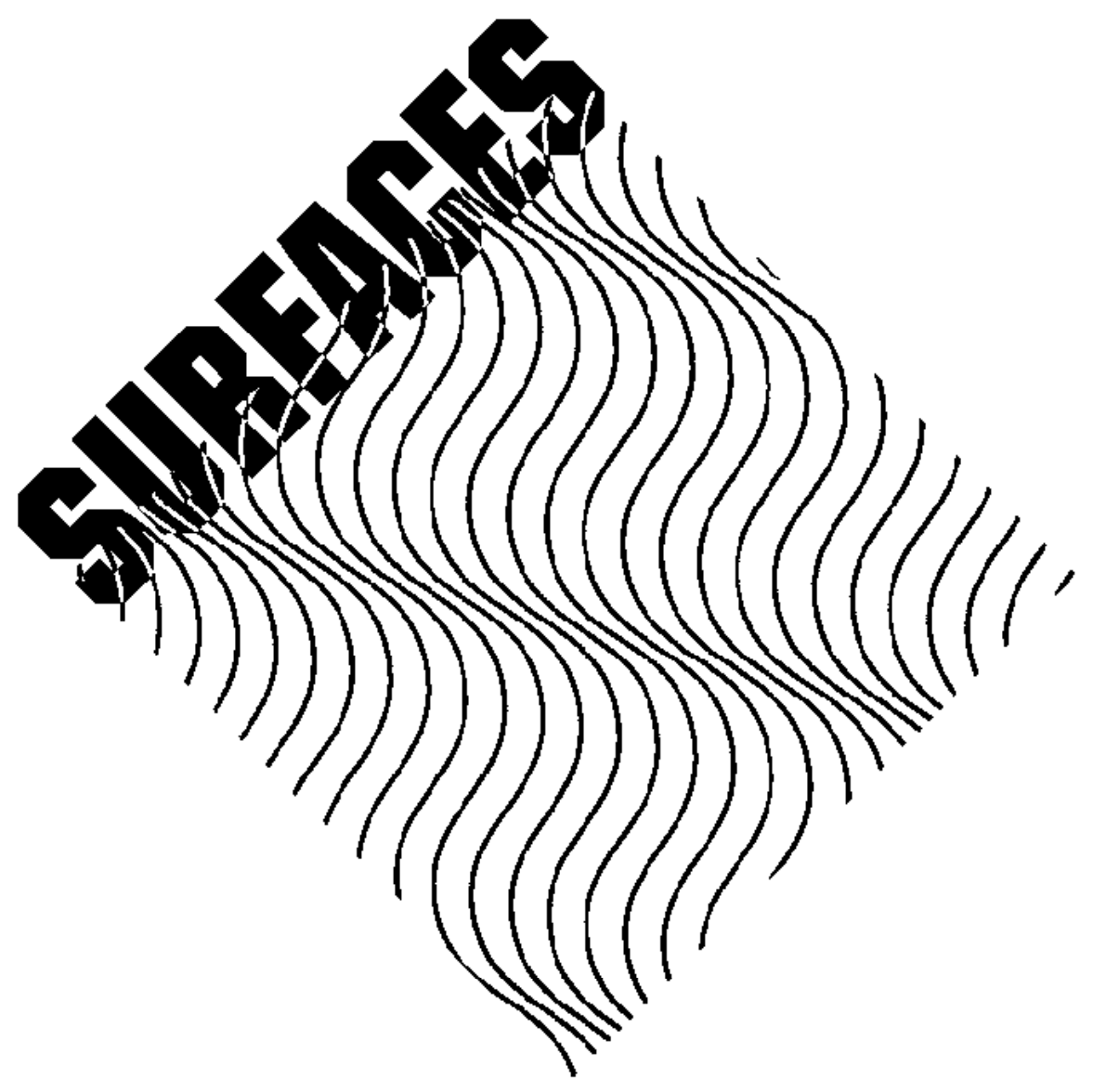

ADAPTING WEB ELECTRONIC LIBRARIES TO ENGLISH STUDIES

Christopher Douglas, Dennis G. Jerz, and Ian Lancashire 


\section{Rédacteur en chef:}

Jean-Claude Guédon

\section{Comité fondateur:}

Wlad Godzich

Walter Moser

Michel Pierssens
Christie McDonald

Antonio Gómez-Moriana

Gilles Bibeau

\section{Remerciements:}

SURFACES peut paraître grâce à un soutien des Presses de l'Université de Montréal, ainsi qu'à une aide matérielle importante (locaux, mobilier, services informatiques) de l'Université de Montréal.

\section{Adresses:}

\section{SURFACES}

Département de littérature comparée Université de Montréal C.P. 6128, succ. Centre-ville Montréal, Qc, Canada H3C 3J7

Tél.: (514) 3435683

Fax: (514) 3435684

Accès sur INTERNET www.pum.umontreal.ca/revues/surfaces

Assistance technique et questions éditoriales: guedon@ere.umontreal.ca

ISSN: $1188-2492$ 


\section{Soumission des textes}

Vous pouvez soumettre vos articles, revues, notes, commentaires ou autres aux éditeurs par courrier électronique, par disquette ou par lettre. En ce qui concerne les notes bibliographiques, veuillez suivre le protocole du MLA. Nous vous demandons également de joindre à votre texte un court résumé de 3 à 4 lignes.

Tout article publié que l'auteur voudra modifier ultérieurement sera de nouveau évalué. Si accepté, il se substituera à la première version avec une nouvelle date et la mention v. 2.

Tout texte reste la propriété de son auteur. Néanmoins, SURFACES demande d'être citée à l'occasion de toute autre publication du texte en question.

\section{Citation des textes}

Pour toute citation, veuillez consulter le document source afin d'obtenir la dernière version du texte qui vous intéresse et vous baser sur la pagination flottante (/pp. $\mathrm{xx} /$ ) plutôt que sur la foliation (pied de page). Si vous n'avez pas accès au courrier électronique, adressez-vous aux éditeurs qui pourront vous vendre une copie papier ou sur disquette. 


\title{
RÉSUMÉ
}

Le département d'anglais de l'Université de Toronto a mis au point UTEL, un site web d'enseignement et de recherche conçu pour mettre en lumière les différentes approches théoriques et méthodologiques de la littérature dans ce départment. Nous défendons la constitution par les universitaires de bibliothèques électroniques départementales afin de rendre disponible des essais, des notes, du matériel de lecture, ainsi que des bases de données. Une infrastructure institutionnelle, avec un système d'évaluation par les pairs et des objectifs cohérents, s'impose pour un tel projet. Il s'agit d'un type de modèle qu'il faut développer puisqu'on ne le retrouve sur le Web ni dans les sites individuels ou commerciaux, ni dans les sites de départements universitaires colligeant le plus souvent des renseignements administratifs.

\begin{abstract}
University of Toronto's Department of English developed UTEL, a teaching and research World Wide Web site designed to foreground the diverse theoretical and methodological approaches in that department's views on literature. We argue that academia needs to build local academic content into electronic libraries by supplying faculty essays, notes, lecture materials, and dedicated databases, all selected and created to mirror the specific purposes and identities of the academics who will use it. Doing so requires a long-term institutional infrastructure with peer review, and coherent goals - a model not found in individual or commercial Web collections, in purely administrative departmental sites, or on the World Wide Web itself.
\end{abstract}


UTEL, the University of Toronto English Library $<$ http://utl2.library.utoronto.ca/www/utel/index.html $>$ is not a general electronic library. It is an undergraduate and graduate teaching / research site designed for the students and faculty of the Department of English at the University of Toronto. The prototype UTEL site was set up on the University of Toronto Library Web server in 1993-94 to make available the on-line re-edition of the Department of English's teaching anthology, Representative Poetry (1912-67). Available on the Research Libraries Group WebDoc, this is the first Web-based historical anthology of English poetry with extensive historical notes. Representative Poetry On-line offers over 2,000 poems by more than 300 poets from Chaucer to Wilfred Owen. Unlike Chadwyck-Healey's impressive poetry database, or other institutional collections of American and British literature, Representative Poetry On-line is selective, critical, and annotated. It includes what one Department of English regarded as the best work the best poets have done, delivers it in the best text (whether printed or manuscript source), annotates the poems, and includes historical prose criticism on the nature of poetry.

Representative Poetry has been compiled by more than two dozen English faculty at Toronto over the past 85 years. The originator of the anthology in 1912 was Professor W. J. Alexander of the University College English Department. Subsequent editors include Northrop Frye (who as a graduate student in the 1930s compiled many of the notes on poets from Donne to Blake) and Marshall McLuhan. Large as it is, the collection remains in development, with non-British and women poets being recent additions. Biographies and more North American poets are an early priority for inclusion. More teaching versions of poems are, as well: for example, the Beowulf and Sir Gawain and the Green Knight are interlinear editions, each line or stanza of original text being followed by a translation.

UTEL ventured beyond poetry in April of 1996, thanks to a grant from the Provost's Information Technology Courseware Development Fund and additional support from the Department of English. The Library was conceptualized from the start, /pp. 5-6/ not 
as an archive of e-texts, but as an organic collection that represented aspects of English studies at the University of Toronto - an extension of what Representative Poetry On-line accomplishes.

UTEL is thus making a particular response to the problem currently facing all Internet denizens: they can define themselves, fashioning an identity against disorder, or they can let themselves be disoriented and unravelled by the uncontrollable forces on-line, as Sherry Turkle and others say. To cultivate the Web for literary and linguistic studies, academia needs to build local academic content into electronic libraries by supplying individual faculty essays, notes, lecture materials, and dedicated databases, all selected and created to mirror the specific purposes of the academics who will use it. "The Web" is one of the less accurate metaphors people now live by, because the Internet in which it flourishes is not two-dimensional and centred but four-dimensional (having breadth, width, and length, and extent over time) and centreless. A long-term institutional infrastructure such as UTEL, limited by peer review and directed by departmental goals, fashions a life-like group identity over time. It thus differs from individual or commercial Web collections or the World Wide Web itself. UTEL-like collections follow an institutional pedagogic design, responsible to the range of interests of those who use them.

All this is overseen by UTEL's Editorial Board, representing many fields and including the Associate Chair of the English Department. The Board sets UTEL objectives and ensures that all contributions are peer-reviewed. Being collaborative, UTEL does not favour one group within the Department. Publishing the work of its faculty, UTEL enhances the reputation of the Department as a whole. The co-sponsorship of the venture by the University's Library through its Web Development Group - builds on a long-existing institutional relationship trusted by even the most untechnological Teachers and researchers. Our on-line offerings are sharply divided between language-based resources ("history of English") and theory / critical texts, and less sharply between research and teaching. Through a locally-crafted Web site like UTEL, which /pp. 6-7/ emphasizes communal contribution, and provides graduate assistants 
with technical knowledge to share with the faculty, a department can forge a communal on-line identity without being divided even further by the new enthusiasm for technology. A quick visit to UTEL will allow the curious reader to view and, if he or she wishes, critique the UTEL literary canon; but more important to the substance of this paper is our discussion of the philosophy which leads us to create a web site that serves us as well as it does. The vast majority of the literary texts we publish are widely available; but what makes UTEL valuable to the University of Toronto is its ability to publish a large sample of the pedagogy, the texts, and the research procedures that (we believe) frame our identity as a community that professes and studies our subject.

UTEL predates the University of Toronto English department central Web site, which offers a wide array of administrative information, such as faculty biographies and course schedules. Created by administrators, it naturally fulfills administrative needs. UTEL enriches this departmental Web presence by presenting its view of what an English department actually does when it is not administering itself.

\section{A Quick Tour of UTEL}

The main UTEL Web page includes links to the five major UTEL Web collections, to several relevant University research projects and a growing collection of undergraduate and graduate courses that use the Internet. In many cases, the authors were not even aware of their colleagues' Web sites, and several others learned how to post their own pages after being tutored by UTEL staff. In addition to the annotated lists of literary links one expects to find on any respectable English site, UTEL offers links to local research databases and project sites by English faculty < http://utl2.library.utoronto.ca/www/utel/index.html\#research>, a joint Library-English collection of modern Canadian poetry $<$ http://www.library.utoronto.ca/www/canpoetry/>, over two dozen of T. English course Web sites $<$ http://utl2.library.utoronto.ca/www/utel/index.html\#courses>, /pp. 7-8/ centres devoted to Northrop Frye 
$<$ http://vicu.utoronto.ca/fryecent.htm> and Marshall McLuhan $<\mathrm{http}: / /$ www.mcluhan.toronto.edu>, four resources for literary criticism <http://utl2.library.utoronto.ca/www/utel/criticism.html>, and faculty-written teaching aids on essay writing and a glossary of critical theory. These works represent some of the best teaching and research efforts of the University of Toronto community. The simple action of putting all these works in in one place has already sparked new projects.

Our History of the English Language collection $<$ http://dev.library.utoronto.ca/utel/diaclang.html> includes links to the Dictionary of Old English project, the Early Modern English Dictionaries Database, the Helsinki Corpus (the first diachronic corpus of the language, from Old English to the 18th century); and a convenient link to the on-lineOED2. These contribute to the richness of the language resources available to members of the University's English community, and are especially important to the many Departmental graduate students who come to the University of Toronto because of its strengths in Medieval studies and the history of the language.

A second major collection is English Composition $<$ http://dev.library.utoronto.ca/utel/complang.html>. Unlike US colleges and universities, Toronto decentralizes the teaching of composition by supporting a policy of writing across the curriculum. English does not teach all students the business of writing. Unsurprisingly, the Engineering Faculty, the Philosophy Department, and the individual college writing laboratories responded to the needs of their own students by creating composition Web sites, even before the English department did. Before joining UTEL, Dennis Jerz built the Web site for the Engineering Writing Centre <http://www.ecf.toronto.edu/ writing/>, which serves students of whom fifty percent speak a language other than English at home; he also benefited from the example of Philosophy, which publishes short papers by different faculty members on how to write essays $<$ http://www.chass.utoronto.ca:8080/philosophy/phlwrite/index.html >./pp. 8-9/ Margaret Procter, the Provost's Advisor on Writing, has 
a Web site on Writing at the University of Toronto that holds a growing number of general writing handbooks and also helps unify the writing instruction offered across several faculties and campuses $<\mathrm{http}$ ://utl1.library.utoronto.ca/www/writing/index.html>.

The Department of English, however, does organize each year some 20 graduate students to teach technical writing to about 400 undergraduate engineering students and employs a rotating body of sessional instructors to teach a first-year half-course in English composition. For the students and instructors involved in these programs, UTEL makes the dispersed local Web resources readily available - instruction that today's students expect to find on-line at any major university - but also contributes its own useful resources to the Internet. These include Linda Hutcheon's oft-requested guide to writing, <http://dev.library.utoronto.ca/utel/language/essay.htm>, the

English Critical Essay, and A.G. Rigg's reference lexicon, Traditional Grammatical Terminology $<$ http://dev.library.utoronto.ca/utel/language/Grammar.htm>. What is now a comprehensive hypertext reference on grammar was originally composed by a medievalist with a manual typewriter; it enjoys a healthy local popularity in both forms. Thanks to the efforts of graduate student Marc Plamondon, Web users can also click their way through an on-line version of Rigg's The English Language: A Historical Reader $<$ http://utl2.library.utoronto.ca/www/utel/language/rigg/Rigg_titlepag e.html>, which provides pop-up windows with parallel selections from the Vulgate, Old English, Wycliffite, and other Bibles. Both faculty members updated their work for the UTEL venue. We also direct students to another popular on-line handout called How not to plagiarize, written by Toronto's writing coordinator, Margaret Procter <"http://utl1.library.utoronto.ca/www/writing/plagsep.html>. The English department had in fact made so many copies of the "master" of this document that the original was many generations removed and, ironically, the credit line had been obliterated - thus /pp. 9-10/ making it impossible for the students to cite properly the Department's own advice against plagiarism. 
Another resource UTEL makes available is a Bibliography Builder, originally written by Dennis Jerz for Engineering students, but now modified to handle MLA style JavaScript $<$ http://utl2.library.utoronto.ca/www/utel/language/bib.html>. The MLA Handbook's 81-page chapter on documentation (4th edition) contains enough slightly differentiated examples to puzzle even advanced students. The Bibliography Builder subdivides the construction of a bibliography entry into a hierarchy of smaller, more manageable tasks. For instance, the user clicks on "Author" and then chooses an option such as "No author, corporate author, single author, multiple authors." After completing the process, the student presses a button to generate the entry, which can then be copied and pasted into a word processor. To fill in the blanks, the student must still locate all the information; using this utility should therefore help the student to learn how to make a bibliography off-line, as well.

Our third Web collection is a table of contents to literary works, sorted by genre <http://dev.library.utoronto.ca/utel/works.html>. UTEL users can select a text, either from the UTEL index, or through a link on their instructor's syllabus. The link brings up a table of contents for the on-line text; users can view by individual chapters, download the entire text, or consult the author page. The flexible search engine allows complex, definable searches of works, in isolation or as parts of user-definable corpora. This collection can be used both by faculty in smart classrooms and by students working alone on essays or reports. In both situations, the typical user explores a single work in hand (the target book, normally a required printed textbook) in the context of a deep hypertext that embodies the historical traditions of English literature and language. Because all texts are searchable, users can quickly discover how keywords and phrases - motifs and themes - found in the printed text are echoed in the hypertext. In this way users can readily see the connections that give unity to literary history.

/pp. 10-11/

Accurately representing a group on-line is necessarily a group effort. A small team assembled the main UTEL site in six months. The Director, Ian Lancashire, collected the team and the e-texts. Two Ph.D. students, Christopher Douglas and Dennis G. Jerz, converted 
prose fiction and non-fiction to HTML format, Web-set faculty contributions, and designed the UTEL Web page. They were succeeded by Marc Plamondon, who added more literary texts and edited the historical English reader. A graduated student, Mark Catt, on contract, devised the UTEL search engine $<$ http://utl2.library.utoronto.ca/www/utel/patterweb.html>. John Bradley's TACTWeb is also available for close analysis of individual texts on-line.

We used SGI UNIX computers in a public computer lab run by the University's computer support group, the Information Commons. There, staff members helped us develop utilities in sed and perl more elaborate than those initially developed for Representative Poetry. We tackled texts published in the CD-ROM accompanying the recent MLA book,Using TACT with Electronic Texts. Most of these e-texts were already heavily marked up, many by the North American Reading Program for the new $O E D$, others by the UTEL Director. We saved time by translating the existing markup rather than starting from scratch. A perl utility written by Dennis Jerz subdivides long electronic texts into Internet-friendly books and chapters, automatically adding headers, navigation links, and labels for the search engine. Such utilities have largely freed us from the drudgery of hand coding (and, as we worked out the kinks in our tagging schemes, re-coding, and re-re-coding).

Many of UTEL's prose works are restricted to the university, which raises the question of whether UTEL might be better suited to an intranet. We argue the answer is no, because all English departments stand to gain from each others' Web sites, both in terms of modeling possibilities and by virtue of the fact that UTEL's texts will eventually make their way into the public domain. Although keeping pace with accepted computer technology within the institution, UTEL also avoids experimental software, nascent encoding languages like the Text Encoding Initiative guidelines /pp. 11-12/ and XML, and full-service on-line Web courses, not because of any disapproval of their worth, but because they are not universally implemented.\&nbsp; Our focus is to manage a transition between an off-line department of individuals who teach and learn in classrooms, 
and publish in paper-print form, and an on-line collective slowly coming into existence. Fundamental changes like this face enormous odds, because no other medium except the printing press has altered the way faculty members teach and undertake research.

The graduate assistants have also been able to spend some of their time interacting directly with faculty. In our large and decentralized English department, where faculty and graduate interaction most often centers on the grading of stacks of undergraduate papers, we all valued this collegiality and the chance to make something of longterm value together. Almost as soon as we started working on UTEL, we were approached by graduate students who were willing to donate their time and /or ideas to the cause - they were attracted to the project's high visibility and the opportunity to develop marketable skills. This enthusiasm for the Internet led the Graduate English Association to enhance its own Web site $<$ http://www.chass.utoronto.ca/ geawww/> - now prominently figured in UTEL beside the official English Department sites <http://www.chass.utoronto.ca:8080/english/> - with lists of links, including calls for papers, job postings, and other topics of interest to those of us just launching into the profession.

As with any representative anthology, questions of canon, copyright, the ready availability of certain texts as opposed to others, and the limits of our own knowledge naturally affect the decisions we have made. We will now turn to these issues.

\section{A Vision for the Future}

UTEL comprises a readable and searchable electronic text library of hundreds of Canadian, American, and British authors. These represent the "canon" as five generations of teachers have seen it. Users of UTEL can approach it through the title of the /pp. 12-13/ work they wish to study, or they can approach the library through the author's name. Most UTEL author pages feature a portrait of the author, a hyperlinked list of the electronic texts which that author has written and which are available on UTEL, a short but comprehensive biographical and bibliographical note, and the Department- 
recommended critical print edition of those texts, which are often used in classrooms. As a start, most of the bio-bibliographical notes have been citations from the Penguin Books Web site.

Eventually, we hope, UTEL authors will be indexed not only in a master Alphabetical list, but also by period, genre, and nationality. Interested students would then be able to browse British Victorian fiction, for example, in order to see what kinds of authors and texts were represented in UTEL. This would aid a comprehensive word or phrase search within a specific body of literature.

One of the documents we added to UTEL was a Glossary of Literary Theory, written by a member of our Department, Greig

Henderson, and a graduate student, Christopher Brown $<$ http://utl2.library.utoronto.ca/www/utel/glossary/index.html>. As with the other two faculty members who donated documents to the library, Henderson had no knowledge of the World Wide Web he did not, indeed, have an email address at that time. But in many ways, this printed Glossary made an ideal web-document - it provided, in alphabetical order, definitions of key literary terms, schools of literary theory, and larger artistic or philosophical movements. The printed entries were cross-referenced to each other, so that, for example, the entry on Structuralism $<$ http://utl2.library.utoronto.ca/www/utel/glossary/Structuralism.html $>$ suggested that the user might also take a look at the entries on Deconstruction or Semiotics. These already-existing crossreferences were made into hyperlinks in the UTEL Web-version of the document, and other hyperlinks were also added when in the body of the entry there was reference to other entries.

After the printed document had been searched and scanned, Christopher Douglas added three different kinds of /pp. 13-14/ "invisible" tags to each entry. First were tags noting all the other main entries which were referred to in the entry, second were tags noting the keywords or ideas that were dealt with in the entries, and the third set of tags made note of all the proper names in the entries. This triple-tagging allows the creation of three distinct indices, 
created by a perl program written by Dennis Jerz, each of which is a separate way into Henderson's Glossary.

The indexing program serves another function: the Glossary is now an on-line document which can be updated. Whenever an entry is revised, or a new entry is created, the program can be run on the Glossary to generate an updated index with the new or revised information. Of equal importance is the fact that it opens up the possibility for other faculty members to get involved: interested members of the English department can contribute or revise entries in their field of expertise. Scholars specializing in the Romantic period, for instance, can take charge of the entry on Romanticism, as well as associated ideas like Imagination, Fancy, and Nature. The Glossary also has potential to be a site of inter-departmental dialogue: different Feminist scholars in the department, for example, may write different accounts of the entries on Feminism, Gender, or Gynocriticism (and others); each single entry would perhaps be composed of several micro-essays on the topic from diverging points of view. Again, the electronic Glossary's strength is that it allows as much - or as little - revision and addition as the department's members wish to contribute.

Does UTEL meet the pedagogical and research needs of all the faculty members in the English Department at the University of Toronto? Beyond the question of the computer literacy of its members, this question is complicated by several factors. First, UTEL is made of texts which are in the public domain - that is, which are out of copyright. Copyright varies from country to country, however. Current law stipulates that works by US authors are copyrighted for 75 years after the date of publication, meaning that as of 1999, UTEL can include only American works which were published before 1924. Works by British authors are copyrighted for 70 years after the death of the author; /pp. 14-15/ thus UTEL can include only those British works by authors who died before 1929 . In Canadian practice, authors are in copyright for 50 years, after the date of the author's death; accordingly, no Canadian work can be included that was published after 1949. For this reason, UTEL does not include many works of mid-to-late twentieth-century literature. 
This restriction has very real consequences for some scholars; outside of Canadian poetry, UTEL has few holdings in contemporary literature and an uneven collection of early twentiethcentury texts. Because a significant portion of writing by women, people of colour and queer authors has been written in this century, the usefulness of UTEL for scholars and teachers in these areas is unfortunately, but necessarily, limited. But copyright need not be an obstacle. These omissions can gradually be supplied as the University's Library acquires site licences for commercial on-line resources, such as Chadwyck-Healey's LION, which UTEL can then incorporate as links. As a site devoted to the English Department's teaching and research needs, UTEL opens up into others' work.

Second is the kind of research undertaken by faculty members of the Department. UTEL, at first glance, would seem to support certain kinds of theoretical and methodological approaches better than others. Those approaches based on close textual analysis, such as New Criticism, Semiotics, or Deconstruction, might find UTEL's ability to search for words and phrases quite useful. On the other hand, those approaches that emphasize the author's biography, or the historical context of the writing, may not be able to make much use of UTEL's capabilities. But even in these two instances there is potential for scholarly innovation. For example, UTEL already has a large number of nineteenth-century texts of American fiction, which can be searched as an entire corpus in order to discover patterns of what tends to be the concerns of the moment. For instance, nineteenth-century American discourse is obsessed with images of siblinghood and twin bodies - both of which were metaphors used to work out national anxieties about the state of the Union in the years leading up to, and following, the Civil War (see Shell, Children of the Earth). UTEL could be used to track the /pp. 15-16/ 
patterns of such metaphors, their ebb and flow, and their transformations over a large body of literature before and after the events of the 1860 s.

UTEL may also become useful for biographically-based research. For example, it has ten of Henry James's novels on-line, which can be searched separately or together for simple words, phrases, and patterns of nearness of one word or phrase to another. More complicated text-analysis of an author's corpus - which might provide the key to a kind of cognitive fingerprint of an author - is more difficult. At this stage, there is no software that reliably dissects text into its parts of speech such as nouns, verbs, adverbial phrases, and so on. Anyone using a word processor's grammar checker knows of commercial systems for the grammatical and syntactic encoding of modern English text, but these have not been developed for literary texts or for older texts or, indeed, for novice users. This work could still be undertaken now - but only after a researcher has painstakingly hand-encoded the entire text in question with information about the parts of speech, and about novelistic distinctions such as dialogue and diegesis (description) and all the complicated variations in between. But the possibility of using this kind of software on the UTEL corpus would make for some interesting new approaches to literary biography. This kind of work might produce, for instance, a comprehensive and statistical comparison between the styles of Henry James, Virginia Woolf, and Ernest Hemingway.

Yet a UTEL so configured would still tend to privilege the needs of researchers working in computational text analysis, editing, and with certain kinds of theoretical approaches. The pressing issue in on-line educational computing is not e-texts or encoding methods, not computerized classrooms or search engines. The issue is how to organize educational sites to enhance their usability for a discipline's researchers and teachers within the university. Current electronic libraries favour the teaching and research methods of those who analyze or edit texts and of those who use a scientific methods in doing so. There is nothing inappropriate about this approach (quite the contrary), but no general-purpose medium for edu-/pp. 16-17/ 
cation, such as the Web, should support one type of theoretical and practical work more fully than another. For this reason, a local discipline-based Web site should be re-conceived as a collection of individual faculty offices, each occupied by an on-line double of a faculty member, each drawing on a UTEL-like electronic resource. Sites of this kind would resemble a network of rudimentary artificial intelligences - although expert systems are probably a more realistic goal - that correspond to current faculty members and that can serve their students and indeed the public with expertise and learning around the clock. The first step towards this goal is the collection of English course pages on the main UTEL page.

Recent speculative science and science fiction has suggested an almost delirious vision of a future in which human minds become translated into online presences. In 1988 Hans Moravec, a computer scientist at Carnegie-Mellon, forecast that in 2018 the technology will exist to capture directly in digital form an individual's thoughts on-line. He wrote only four years after science-fiction writer William Gibson's Neuromancer set at about this future time, depicted the virtual lives of Henry Case and Dixie Flatline on a net eventually governed by a joint artificial intelligence code-named Wintermute and Neuromancer. Ten years later another Nebula-award winner, Canadian Robert Sawyer, Portrayed in The Terminal Experiment (1995) a psychological case study of immortality obtained by a Toronto doctor who made three virtual copies of his mind, released into the Internet.

Such speculation is far from today's crude software agents, the gobots that conduct intelligent on-line searches for clients and report back results meeting very selective criteria. Yet perhaps among these visions the trajectory of technological innovation and can be discerned. The Internet as it is now taking shape is akin to a huge and, for many undergraduates, unmanageable set of information banks. In the face of this vast entity - whose vastness and diversity are its strengths - intelligent advice on how to harness it must be in place. Just as universities place information in libraries and situate the intelligence to negotiate that knowledge base in faculty members and librarians, so on-line universities should supplement /pp. 17-18/ 
their Web sites with on-line intelligences in the form of faculty online doubles. Such on-line presences have an important pedagogical role in that they help students negotiate the wilderness of the Internet's offerings.

A faculty member's Web page is potentially such an on-line professional double. It can echo a scholar's public productivity: course descriptions, bibliographies, schedules, and texts; selfadministerable student tests; lecture notes; curriculum vitae; faq sheets; and interactive question-answering programs. Most of this technology exists today, but UTEL-like Web sites in this context may have to be re-conceptualized as supplying the needs of individual teacher-researchers as on-line simulacra if university departments are to keep pace with competition, especially from private, industry-run educational institutes. Whether faculty will embrace the concept of on-line doubles is uncertain, given their implications for labor-management relations within our postsecondary institutions. Some faculty may be concerned that, in these times of diminishing faculty-student ratios, a small army of such electronic doppelgangers might conceivablyreplace them. However, faculty now write textbooks, which are their teaching doubles; and departments teach from the work of such "doubles" who are not on staff personally. Copyright laws will further protect the faculty content providers who create their own doubles within the context of a Departmental site.

These are some of the larger issues at work in designing our English Department's Web site. In a sense, UTEL is the Department taking its own present and future pedagogic and research needs into its own hands - a complex task in which some needs are addressed more easily than others. We hope that this paper argues for the value of crafted Departmental sites as ways of shaping a long-term, evolving identity. They have a role to play, as commercial databases do. One mission of the post-secondary institution today is to teach, but that teaching has some work to do before it can make use of the massive forests of electronic text and data on the Internet. Every course asks for its own well-tended academic garden, comfortable living quarters for the teacher and the student. /pp. 18-19/ 


\section{Christopher Douglas Dennis G. Jerz Ian Lancashire Department of English University of Toronto}

\section{References}

Gibson, William. Neuromancer. New York: Ace Books, 1984.

Lancashire, Ian, in collaboration with John Bradley, Willard McCarty, Michael Stairs, and T. R. Wooldridge. Using TACT with Electronic Texts: Text Analysis Computing Tools Version 2.1. New York: MLA, 1996. With CD-ROM.

Lancashire, Ian. "<I>Representative Poetry On- Line $</$ I $>$ : Updating a Historical English Teaching Anthology." Scholarly Discourse and Computing Technology: Perspectives on Pedagogy, Research, and Dissemination in the Humanities. Ed. R. G. Siemens and William Winder. Printed in Text Technology and on-line in Computing in the Humanities Working Papers.

Lancashire, Ian. <http://www.library.utoronto.ca/utel/ rp/rp.html" $>$ Representative Poetry On-line. Toronto: University of Toronto Library, 1994-. Version 2.0. 1996.

Moravec, Hans. Mind Children: The Future of Robot and Human Intelligence. Cambridge: Harvard University Press, 1988.

Poster, Mark. The Second Media Age. Cambridge, Mass.: Polity Press, 1995.

Sawyer, Robert. The Terminal Experiment..New York: HarperPrism, 1995.

Shell, Marc. The Children of the Earth. New York: Oxford University Press, 1993.

Turkle, Sherry. Life on the Screen: Identity in the Age of the Internet. New York: Simon and Schuster, 1995.

/p. 19/ 